\title{
Spatial Structure Analysis of Benthic Ecosystem Based on Geospatial Approach at Parang Islands, Karimunjawa National Park, Central Java, Indonesia
}

\author{
Muhammad Helmi $^{1,2^{*}}$, Afrina Aysira ${ }^{3}$, Munasik ${ }^{2,4}$, Anindya Wirasatria ${ }^{1,2}$, Rikha Widiaratih ${ }^{1,2}$, \\ and Raden Ario ${ }^{4}$ \\ I'Ocanography Department, Faculty of Fisheries and Marine Science, \\ Diponegoro University, Semarang, Indonesia \\ Center of Excellence for Science and Technology (PUI) - Center for Coastal Disaster Mitigation \\ ${ }^{4}$ Marine Sciences Department, Faculty of Fisheries and Marine Science, \\ Diponegoro University, Semarang, Indonesia \\ Email: *muhammadhelmi69@gmail.com
}

\begin{abstract}
This research examines the spatial structure of live coral based on its patches on a geospatial data. Spatial structure is a part of the landscape ecology approach that has been applied on terrestrial and applied on marine ecosystems on this research. It is including Mean Shape Index (MSI), Number of Patches (NumP), Mean Patch Size (MPS), Total Seascape Area (TLA) and Class Area (CA). Live coral patches were extracted based on GeoEye-1 satellite image with several tasks, such as ortho-rectification, atmospheric calibration, water column correction; Lyzenga transform and supervised classification. A field survey was done in 2015 - 2016 with 38 verification sites and 16 sites of manta tow. Live coral patches produced a significant accuracy (overall accuracy $=84.1 \%$, user accuracy= $81.8 \%$, producer accuracy $=90 \%$, and Kappa Index $k=0.81 \%$ ). Live coral was found 35\% (CA: 201.99 ha) of seascape TLA area 814.19 ha and spread over a large number of patches (NumP: 5613-21087 patches). The live coral had a mean shape index (MSI) between 1.23 to 1.25 and the average size of patches (MPS) between 0.0029 0.0082. This approach could be applied to reef ecosystems and becomes a baseline data to anticipate future damage.
\end{abstract}

Keywords: Spatial structure, benthic ecosystem, patches, live coral, and Karimunjawa

\section{INTRODUCTION}

Coral reef ecosystems scattered across the world's coral reef triangle are under serious threats and anthropogenic is identified as the main issue of such damage (Burke et al., 2012). The threat of this damage is influenced by the climate change impact (Sunaryo, et al. 2018), especially the rise in sea surface temperature that affects the coral bleaching. In Indonesia, the status of coral reef condition shows that $60 \%$ is severely damaged (LIPI, 2107). Parang and Kumbang islands are part of Parang Island consist of coral reef ecosystems that form an ecological unity. Parang Islands of Karimunjawa Islands National Park has extensive coral reef ecosystem (Helmi et al, 2018a). Residents already live in this area before the national park establish. Most of the inhabitants depend on coral reef ecosystems for fishing, aquaculture, tourism, sailing and marine transport (Helmi et al, 2018b). The mapping of reef ecosystems is done periodically to determine the existing status and extent of damage as a basis for planning and management in the region. This research aims to 1) conduct a mapping of variations of shallow water habitats existing in coral reef ecosystems; 2) to examine the coral reef ecosystems covering percent live coral cover and spatial structure of living corals; and 3) trends in sea surface temperature rise and the potential for coral bleaching. Shallow water habitat mapping is conducted using GeoEye-1 multispectral satellite data with $1.8 \mathrm{~m} \times 1.8 \mathrm{~m}$ resolution that has not been done before. Data collection existed give information about 
status of live coral cover and quantitative coral reef structure with ecological landscape approach. Implementation of the landscape ecology approach to coral reef ecosystems is the novelties of this study. The landscape structure is part of an ecological characteristics based on a strongly spatial form of an ecosystem (McGarigal and Marks, 1995). The landscape spatial structure applied are Total Sescape Area, CA (Class Area), MSI (Mean Shape Index), NumP (Numb of Patches), MPS (Mean Patch Size). A detailed map of shallow water habitats, quantitative spatial structures of living coral reefs and rising sea surface temperature trends are becoming complementary data collection of coral reefs that have not been integrated previously.

\section{DATA AND METHOD}

Digital satellite data processing was performed for radiometric correction (Weragodathenna et al., 2000; Werdell et al., 2003; and Reshitnyk et al., 2014). Rectification for geometric correction was done using Polynomial and Nearest Neighbor methods (Lillesand and Kiefer, 1994; Pineda et al., 2005; and Hamylton et al., 2011, Hartoko, et al., 2016, and Satriadi et al., 2018). To improve the visual display quality of satellite data, we used the Contrast Enhancement Method, Composite Color and Image Data Fusion.

Coral reef ecosystem mapping was conducted using a water attenuation model for water column correction (Mumby et al., 1998; Kabiri et al., 2014; El-Askary et al., 2014; and Wahidin, et al., 2015), the Lyzenga Transform Method to highlight the spectral response of shallow water substrate (Lyzenga. 1978) and Green et al. 2000). Shallow water ecosystem mapping was performed using Supervised Classification Method (O'Neill et al., 2013; Mustapha et al., 2014; Valle et al., 2015, and Setyawidati, et al., 2017) and contextual editing (Green et al. 2004).

Manta tow survey was carried out at 16 locations to verify the results of the mapping and to determine the condition of coral reefs. Manta Tow was conducted using two minute observations, visibility $10-12 \mathrm{~m}$, a speed of 1.5 knots, parallel observations on the reef crest and reef slope (Munasik. 2009). Accuracy tests of shallow coral reef ecosystem (Green et al. 2004) used the Confusion Matrix and Kappa Index methods.

Confusion Matrix is an objective method and accuracy because the accuracy can be obtained overall and each accuracy of object that was mapped (Sutanto. 2013). Kappa index is discrete multivariate techniques to study accuracy using statistical analysis Khat (Cohen, 1960 in Sutanto, 2013) with the following algorithm.

$$
K=\frac{N \sum_{i=1}^{r} x_{i j}-N \sum_{i=1}^{r}\left(x_{i+} \cdot x_{+i}\right)}{N^{2}-\sum_{i=1}^{r}\left(x_{i+} \cdot x_{+i}\right)}
$$

Where:

$$
\begin{aligned}
\mathrm{r} & =\text { Number of lines in the confusion matrix } \\
x_{i j} & =\text { Number of observations on the first line and on the main diagonal } \\
x_{i+} & =\text { Number of observations on the first line (the number of right edges of the matrix) } \\
x_{+i} & =\text { Number of observations in the strip I (the number at the bottom of the matrix) } \\
\mathrm{N} & =\text { The total number of observations (pixels) on the matrix (the number in the lower right } \\
& \text { corner) }
\end{aligned}
$$

$\mathrm{K}$ value is between $0-1$. If both accuracy value of each be close to 1 , imply the possibility of such accuracy occurred by chance is 0 (not purely coincidental). If the negative value of $\mathrm{K}$ obtained, that means the mapping and modeling produced is very poor. 


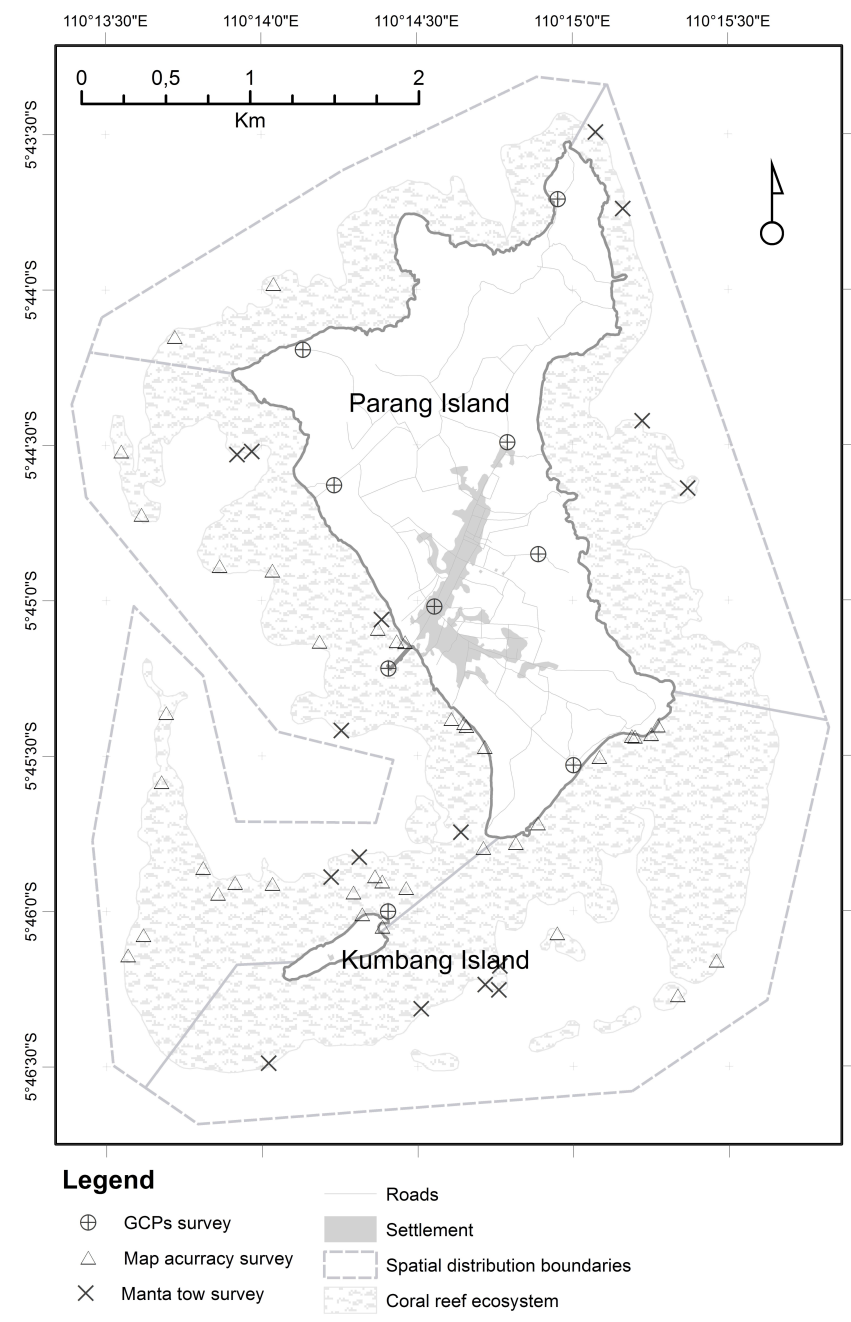

Figure 1. Study area

The spatial structure studied was live coral using the approach developed by McGarigal and Marks, 1994 and McGarigal and Marks, 1995 include: Total Seascape Area, CA (Class Area), MSI (Mean Shape Index), NumP (Numb. of Patches), MPS (Mean Patch Size).

The spatial structure is part of the ecological approach from the ecological scientific development (Stow, 1993). The spatial structure of living coral reefs in the study area was divided into four parts, namely the north, east, west and south. And subscripts algorithm for calculation of spatial structure as follows;

$$
\begin{array}{rlrl}
T A & =\mathrm{A}\left(\frac{1}{10.000}\right) & M P S & =\frac{\sum_{j=1}^{n} a_{i j}}{n_{i}}\left(\frac{1}{10.000}\right) \\
C A & =\sum_{j=1}^{n} a_{i j}\left(\frac{1}{10.000}\right) & M S I & =\frac{\sum_{j=1}^{n}\left(\frac{P_{i j}}{2 \sqrt{\mu \cdot a_{i j}}}\right)}{n_{i}} \\
\mathrm{NP} & =n_{i} &
\end{array}
$$




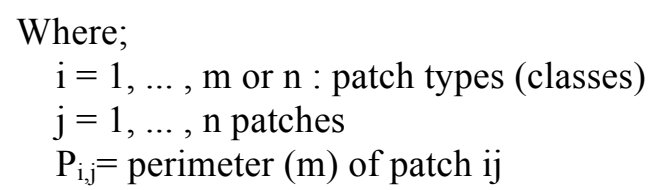
$\mathrm{a}_{\mathrm{i}, \mathrm{j}}=\operatorname{area}\left(\mathrm{m}^{2}\right)$ of patch ij
$\mathrm{A}=$ Total landscape area $\left(\mathrm{m}^{2}\right)$
$\mathrm{n}=\mathrm{n}_{\mathrm{i}}$ number of patches in the landscape of patch type (class) $\mathrm{i}$

TA equals the area $(\mathrm{m} 2)$ of the coral reef ecosystem, divided by 10,000 (to convert to hectares). TA excludes the area of any background patches within the coral reef ecosystem Sum of areas of all patches in the landscape. CA equals the sum of the areas $\left(\mathrm{m}^{2}\right)$ of all live coral patches of the corresponding patch type, divided by 10,000 . NP equals to the number of live coral patches of the corresponding patch type (class). MPS equals the sum of the areas $\left(\mathrm{m}^{2}\right)$ of all live coral patches of the corresponding patch type, divided by the number of patches of the same type, divided by 10,000 (to convert to hectares). MSI equals the sum of live coral patch perimeter $(\mathrm{m})$ divided by the square root of patch area $(\mathrm{m})$ for each patch of the corresponding patch type, adjusted by a constant to adjust for a circular standard (vector).

\section{RESULTS AND DISCUSSION}

GeoEye-1 Satellite Data has coverage of clouds $0 \%$. Geometry Correction of GeoEye-1 satellite imagery $(0.5 \mathrm{~m}$ spatial resolution) has been done using 7 GCPs produce a significant geometric accuracy $\mathrm{RSME}=0.87$ with $0,4 \mathrm{~m}$ accuracy in the field.

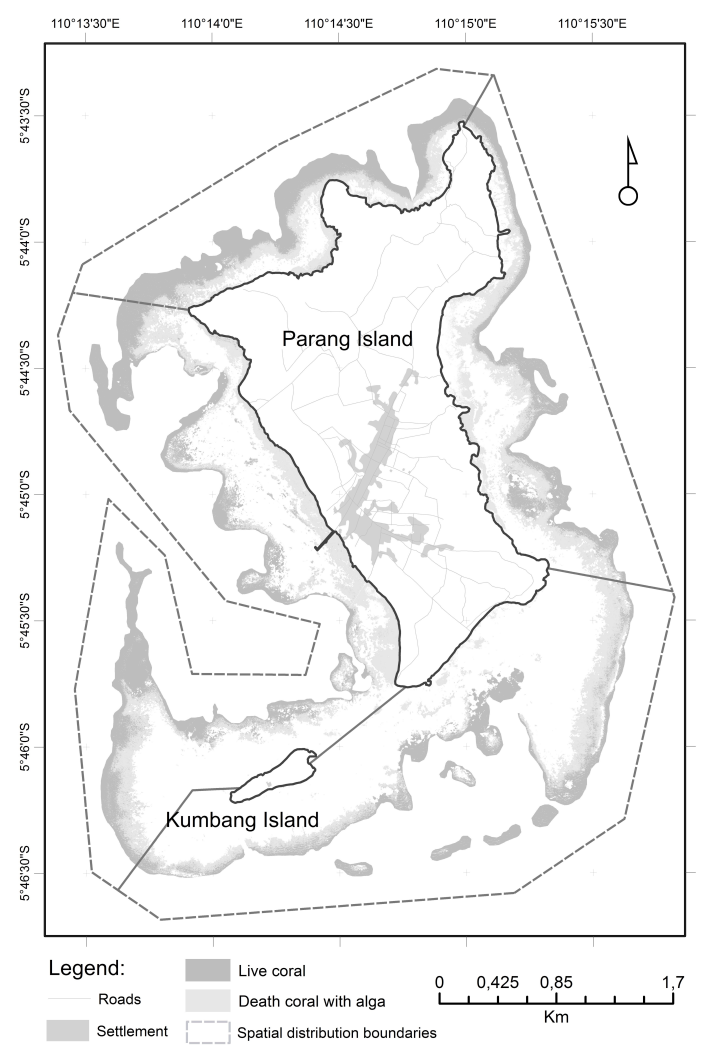

Figure 2. Spatial distribution of Live Coral and DCA (Dead Coral with Alga)

Results for reef mapping are shown in Figure 2. The results of the survey conducted give you a map of coral reef ecosystems that have quality over all accuracy $=84.1 \%$ or higher than the tolerable accuracy (80\%). Producer Accuracy and User Accuracy in each category are mapped according to the ecosystem 
with has high accuracy (above the rated tolerable accuracy $=80 \%$ ). Statistical analysis shows that the coral reef ecosystem maps produced in the area of Parang Island is accurate and can be used for studies that require high accuracy of the mapping results. Kappa Value Index $(\mathrm{k}=0.81)$ was obtained in the results of this analysis shows that this mapping accuracy is positive or considered as good and closed to the value of high accuracy (highest score $=1$ ).

Coral reef habitat area obtained is 814.22 ha. There is live coral reef of 202.01 ha $(49.75 \%)$ and coral reefs die 204 ha $(50.25 \%)$ that were found in the area of coral reefs. The results of this study indicate that the area of Live and Death Coral is the $49.86 \%$ (406.01 ha) of coral reef ecosystems in the study area.

Table 3. Spatial distribution of live and death coral in four areas at Parang Islands

\begin{tabular}{|c|c|c|c|c|c|c|c|}
\hline No. & Area & $\begin{array}{c}\text { Live Coral } \\
\text { (ha) }\end{array}$ & $\%$ & $\begin{array}{c}\text { Death Coral } \\
(\mathrm{Ha})\end{array}$ & $\%$ & $\begin{array}{c}\text { Coral Reef } \\
\text { Ecosystem (ha) }\end{array}$ & $\%$ \\
\hline 1. & Western area & 33,95 & 16,81 & 47,13 & 23,11 & 136,68 & 16,79 \\
\hline 2. & Southern area & 78,21 & 38,72 & 81,8 & 40,11 & 305,17 & 37,48 \\
\hline 3. & Eastern area & 46,07 & 22,81 & 29,4 & 14,42 & 94,5 & 11,61 \\
\hline \multirow[t]{2}{*}{4.} & Northern area & 43,76 & 21,66 & 45,59 & 22,36 & 277,84 & 34,12 \\
\hline & & 201,99 & & 203,92 & & 814,19 & \\
\hline
\end{tabular}

The table shows that coral reefs live and dead coral reefs are spread almost evenly across the water of Pulau Parang diversity is relatively complex spatial structures in particular on the number of patches, mean patch size and class area.

Table 4. Live coral spatial structure.

\begin{tabular}{llrrrrr}
\hline No. & \multicolumn{1}{c}{ Area } & $\begin{array}{c}\text { MSI } \\
\text { (Mean } \\
\text { Shape } \\
\text { Index) }\end{array}$ & $\begin{array}{c}\text { NumP } \\
\text { (Numb. Of } \\
\text { Patches) }\end{array}$ & $\begin{array}{c}\text { MPS (Mean } \\
\text { Patch Size) }\end{array}$ & $\begin{array}{c}\text { TLA (Total } \\
\text { Lanscape } \\
\text { Area) ALL } \\
\text { Class Area }\end{array}$ & $\begin{array}{c}\text { CA (Class } \\
\text { Area) }\end{array}$ \\
\hline 1. & Western area & 1,25 & 21087,00 & 0,0037 & 305,12 & 78,21 \\
2. & Southern area & 1,26 & 14888,00 & 0,0029 & 277,81 & 43,76 \\
3. & Eastern area & 1,24 & 8529,00 & 0,0040 & 136,54 & 33,95 \\
4. & Northern area & 1,23 & 5613,00 & 0,0082 & 94,48 & 46,07 \\
\hline
\end{tabular}

The dead coral (50.25\%) is found more dominant than live coral $(49.75 \%)$. The largest living coral reef is located in the western part of the islands (78.2 ha) spread at 2.1087 patches with Mean Shape Index Irregular (MSI=1.25) and very small size of Mean Patch Size (MPS=0.0037ha). Karimunjawa national park needs to improve the integrated surveillance and rehabilitation efforts in Parang Island. These rehabilitation priority areas could be focused on the area of dead coral and surveillance at live coral on this research. Surveillance and rehabilitation needs to be done in an integrated manner involving Pokmaswas (Community Watch Group), Polhut (Forest Police), and related with stakeholder, which are under the coordination of BTN Karimunjawa Central Java.

\section{CONCLUSIONS}

GeoEye-1 satellite imagery (spatial res. $5 \mathrm{~m}$ ) can be used for detail mapping of live and death coral with significant accuracy (over all accuracy $=84.1 \%$, user accuracy $=81.8 \%$, producer accuracy $=90 \%$, and Kappa Index $\mathrm{k}=0.81 \%)$. Dead coral $(50.25 \%)$ is found more dominant than live coral (49.75\%). At the western side of Parang Islands, was found the most widespread of seabed habitat (305.17 ha) and also 
found the most extensive of live (78.21 ha) and dead coral ( $81.8 \mathrm{ha})$. The largest living coral reef found in the western islands of 78.2 ha spread over 21087 patches with the Irregular Mean Shape Index (MSI = $1.25)$ and has a very small Mean Patch Size (MPS $=0.0037 \mathrm{ha})$.

\section{ACKNOWLEDGEMENTS}

Thanks to PUI PKMBRP Diponegoro University and PT. Waindo SpecTerra for the assistance in the use of Ocean Remote Sensing Laboratory facilities, ArcGIS software version 10.1 and high-resolution of satellite data GeoEye-1 of the study area.

\section{REFERENCES}

Bruno, J.F.; E.R. Selig; K.S. Casey; C.A. Page; B.L. Willis; C.D. Harvell; H. Sweatman, and A.M. Melendy. 2007. Thermal Stress and Coral Cover as Drivers of Coral Disease Outbreaks.PLoS Biology, 5:1220-1227.

Habibi, A.; N. Setiasih dan J. Sartin. 2010. Satu Dekade Pemantauan Reef Check: Kondisi dan Kecenderungan pada Terumbu Karang Indonesia. Laporan Hasil Survei. Yayasan Reef Check Indonesia. hlm. 7-21.

Halpern, B.S.; S. Walbridge; K.A. Selkoe; C.V. Kappel; F. Micheli; C. D’Agrosa; J.F. Bruno; K.S. Casey; C. Ebert; H.E. Fox; R. Fujita; D. Heinemann; H.S. Lenihan; E.M.P. Madin; M.T. Perry; E.R. Selig; M. Spalding; R. Steneck; and R. Watson. 2008. A Global Map of Human Impact on Marine Ecosystems. Science, Int. Journal. 319, 948 DOI: 10.1126/science.1149345.

Hamylton, S. M. and T. 2011. Geomorphological Modeling of Tropical Marine Landscapes: Optical Remote Sensing, Patches and Spatial Statistics. Continental Shelf Research. Elsevier. Int. Journal, 31:151-161.

Leu, M.; S.E. Hanser; and S.T. Knick. 2008. The Human Footprint in the West: A Large-Scale Analysis of Anthropogenic Impacts. Ecological Applications. Int. Journal. 18:1119-1139

Lillesand, T. M.; R. W. Kiefer and J. Chipman. 2008. Remote Sensing and Image Interpretation. 6th Edition. John Wiley and Sons. New York.

McGarigal, K. and B.J. Marks. 1994. Spatial Pattern Analysis Program for Quantifying Landscape Structure. Fragstats User Guidelines Ver. 2.0. Forest Science Department, Oregon State University, Corvallis. USA.

Munasik. 2009. Konservasi Terumbu Karang. Cetakan 1, Badan Penerbit Universitas Diponegoro. Semarang. hlm. 38-50.

Stow, D. A. 1993. The Role of Geographic Information Systems for Landscape Ecological Studies Landscape Ecology and GIS. Taylor and Francis Ltd. London.

Sutanto. 2013. Metode Penelitian Penginderaan Jauh. Badan Penerbit Fakultas Geografi (BPFG), Universitas Gadjah Mada. Yogyakarta. hlm 65-78.

Burke, L, M. Spalding, K. Reytar, \& A Perry. 2012. Menengok Kembali Terumbu Karang yang Terancam di Segitiga Terumbu Karang (Translated). World Resources Institude. Scientific Report, pp 1166.

Pineda, B. J.; M. A. Liceaga-Correa; H. Hernandez-Nunez, and R. Poche-Hernandez. 2005. Using Aerial Video to Train the Supervised Classification Of Landsat TM Imagery For Coral Reef Habitats Mapping. Environmental Monitoring and Assessment 105: 145-164. DOI: 10.1007/s10661-0053499-y.

El-Askary, H., S. H. Abd El-Mawla, J. Li, M. M. El-Hattab, \& M. El-Raey. 2014. Change detection of coral reef habitat using Landsat-5 TM, Landsat 7 ETM+ and Landsat 8 OLI data in the Red Sea (Hurghada, Egypt). International Journal of Remote Sensing, 2014, Vol. 35, No. 6.

Green, E. P., P. J. Mumby, A. J. Edwards, \& Clark, C. D. 2000. Remote sensing handbook for tropical coastal management. Paris: UNESCO. 
Kabiri, K., H. Rezai, \& M. Moradi. 2014. Coral reefs mapping using parasailing aerial photography feasibility study: Kish Islands, Persian Gulf. Springer science + business media Dordrecht. J Coast Conserv, 18: 691-699.

KKP (Kementerian Kelautan dan Perikanan) RI. 2013. Penyusunan Dataset Geospasial untuk Rencana Zonasi Kabupaten Banggai Kepulauan, Provinsi Sulawesi Tengah. Laporan Akhir. Direktorat Penataan Ruang Pesisir dan Laut. Kementerian Kelautan dan Perikanan. Jakarta.

Lyzenga, D.R. 1978. Passive remote sensing techniques for mapping water depth and bottom features. Applied optics, 1(17), 379-383.

Mumby, P. J., Clark, C.D., Green, E.P., \&Edwards, A.J.1998. The practical benefits of water column correction and contextual editing formapping coral reefs. International Journal of Remote Sensing, 1(19), 203-210.

Mustapha, M.A., T. Lihan, \& L.I. Khalid. 2014. Coral Reef and Associated Habitat mapping Using Alos Satellite Imagery. Sains Malaysia 43, 9:1363-1371.

Nababan, M. G, I. B. Martani, R. Sulisyati, P. Prihatinningsih, Mulayadi, T. Kartawijaya, R. Prasetia, R. Tasrif, Ripanto, \& Y. Syaifudin. 2012. Zonasi Taman Nasional Karimunjawa Tahun 2012. Program Report of Balai Taman Nasional Karimunjawa, Ditjen PHKA, Ministry of Forestry. Semarang, pp 15-70.

O’Neill J. D., \& M. Costa. 2013. Mapping eelgrass (Zostera marina) in the Gulf Islands National Park Reserve of Canada using high spatial resolution satellite and airborne imagery. Elsevier. Remote Sensing of Environment 133 (2013) 152-167.

SEDAC (Socioeconomic Data and Applications Center) USA. 2005a. Global Human Influence Index (HII). Last of the Wild Data Version 2 (LWP-2), WCS (Wildlife Conservation Society) and CIESIN (Center for International Earth Science Information Network). New York.

SEDAC (Socioeconomic Data and Applications Center) USA. 2005b. Global Human Footprint Data Set (HF). Last of the Wild Data Version 2 (LWP-2). WCS (Wildlife Conservation Society) and CIESIN (Center for International Earth Science Information Network). New York.

Selkoe, K. A., B.S. Halpern, C.M. Ebert, E.C. Franklin, E.R. Selig, K.S. Casey, J. Bruno, \& R.J. Toonen.2009. A Map of Human Impacts to a "Pristine" Coral Reef Ecosystem,the Papahanaumokuakea Marine National.

Valle, M., V. Pala, V. Lafon, A. Dehouck, J. M. Garmendia, A. Borja, \& G. Chust. 2015. Mapping estuarine habitats using airborne hyperspectral imagery, with special focus on seagrass meadows. Elsevier. Estuarine, Coastal and Shelf Science 164 (2015) 433-442.

Wahidin, N., V. P. Siregar, B. Nababan, I. Jaya, \& S. Wouthuyzen. 2015. Object-based image analysis for coral reef benthic habitat mapping with several classification algorithms. Procedia Environmental Sciences 24, page: $222-227$.

M. Helmi, Purwanto, W. Atmodjo and P. Subardjo, and A. Aysira, 2018a, "Benthic Diversity Mapping and Analysis Base on Remote Sensing and Seascape Ecology Approach at Parang Islands, Karimunjawa National Park, Indonesia", International Journal of Civil Engineering and Technology (IJCIET), Vol. 9, No. 11, pp. 227-235.

Satriadi, A., M. Helmi, and R. Redyansah, 2018, "Numerical Modeling of Tsunami in Jember Regency", Asian Jr. of Microbiol. Biotech. Env. Sc., Vol. 20, No. 3, pp. 87-91.

Setyawidati, N., A. H. Kaimuddin, I. P. Wati, M. Helmi, I. Widowati, and N. Rossi, 2017, "Percentage Cover, Biomass, Distribution, and Potential Habitat Mapping of Natural Macroalgae, based on High-resolution Satellite Data and in Situ Monitoring, at Libukang Island, Malasoro Bay, Indonesia", J. Appl. Phycol, Springer Science+Business Media B.V., DOI 10.1007/s10811017-1208-1.

Helmi, M., A. Satriadi, A. A. D. Suryoputro, J. Marwoto, H. Stiyono, and Hariyadi, 2018b, "Rehabilitation Priority Area Assessment on Death Coral using Cell Based Modeling Approach 
at Parang Islands, Karimunjawa National Park, Indonesia", International Journal of Civil Engineering and Technology (IJCIET), IAEME Publication, Vol. 9, No. 11, pp. 2949-2961.

Sunaryo, Ambariyanto, D. N. Sugianto, M. Helmi, A. H. Kaimuddin, A. Indarjo, 2018 "Risk Analysis of Coastal Disaster of Semarang City, Indonesia," 2018. ICENIS E3S Web of Conferences, 31, 12009, DOI.org/10.1051/e3sconf/20183112009.

Hartoko, A., M. Helmi, M. Sukarno, Hariyadi, 2016, "Spatial Tsunami Wave Modelling for The South Java Coastal Area, Indonesia", International Journal of GEOMATE, Vol. 11, Issue 25, pp. 24552460. 